\section{COSMETIC AND RESTORATIVE DEVELOPMENTS}

The British Academy of Cosmetic Dentistry (BACD) will be on stand B08 at this year's BDTA Dental Showcase, providing aesthetic surgeons and general dental practitioners with information on all the latest developments in the ever-changing world of aesthetic and restorative dental work.

The field of aesthetic dentistry is changing rapidly and becoming more accessible to general practitioners, with the emphasis shifting away from the pursuit of the artificial 'perfect smile' to more accessible, minimally invasive procedures such as alignment or bleaching that require less expense and training whilst producing more natural results.

The helpful BACD team looks forward to informing visitors about the work of this esteemed body, which hopes to foster continuous learning and excellence in the areas of cosmetic and restorative dentistry. Visitors to the stand can discover the benefits of BACD Accreditation and the group's well-regarded Study Clubs, as well as information on the group's own conference in November, 'Something To Smile About! Maximum Aesthetics Minimum Intervention'. Reader response number 61

\title{
UNSWERVING COMMITMENT TO PROSTHESES
}

Restorative dentists from all over the country will be able to discover how the CosTech Elite team could help them raise the standard of their work to new heights at the 2011 BDTA Dental Showcase.

CosTech Elite employs only the best GDC-registered managers and technicians to produce its range of excellent dental prostheses, including DIO abutments and unique products such as ZirconArch and Thineers. Their unswerving commitment, attention to detail and rigorous quality control standards create forensically detailed implant and denture pieces, fulfilling the crucial need for pinpoint accuracy required by surgeons wishing to carry out effective and durable restorative work.

Communicating well with its clients and providing outstanding customer service is another key priority at CosTech Elite. The company takes particular pride in its ELITE7 courier service, which carries a money back guarantee.

Located at stand B21, the CosTech Elite delegation will be pleased to enlighten visitors on the full extensive range of products and services offered by the company's laboratory in Kent.

Reader response number 62

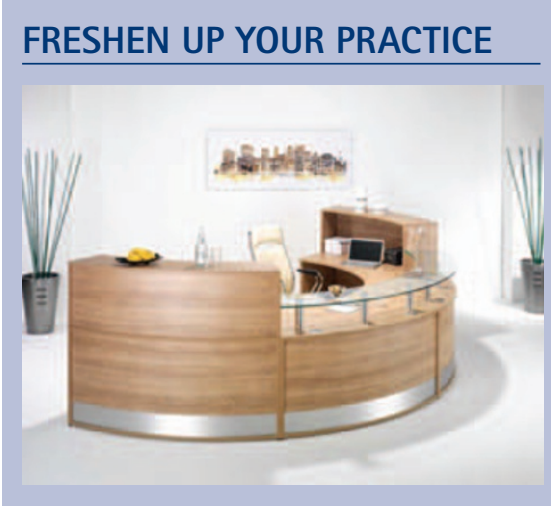

If you're looking for ideas to freshen up your practice waiting area or want help with your practice marketing material, make a point of visiting Admor's stand at the BDTA 2011 Dental Showcase.

Admor's team of experts understand how dental practices work and how important the waiting area is in creating a good impression. From storage to seating, backed by years of experience, Admor can help you create the best in comfort, style and efficiency for your patients and your budget.

With an extensive range of specialist dental practice stationery products to choose from, Admor offers business cards, leaflets, promotional flyers and more to promote your practice.

Come and meet the team at BDTA on stand C05 who will be happy to offer free advice and guidance on the whole range of Admor products. Reader response number 63

\section{A STUNNING ENDODONTIC RANGE, TOP SELLERS AND ACCESSORIES}

\section{Quality Endodontic Distributors}

Limited (QED) will be displaying their full endodontic range at this year's BDTA Dental Showcase, including some exciting new products. Visit stand U06 for a complete update.

The Reciproc file will be demonstrated for the first time at the BDTA; this one file system is the way forward in endodontics. The cordless Superendo B\&L-beta backfill and Superendo B\&tL-alpha II obturation devices will also be exhibited, along with QED's Gutta Percha Trimmer, which cuts the end off GP Points at the touch of a button; Morita's Root ZX Mini, which is equally stunning;

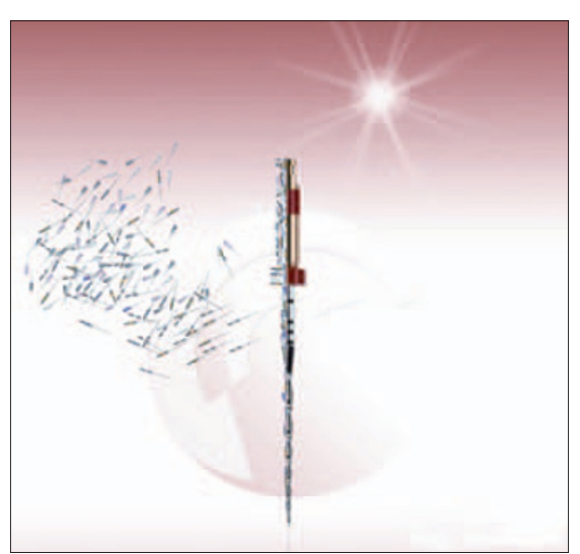

their complete range of irrigants and disinfectants; the famous Angelus MTA, the most popular endodontic repair material and the first MTA based sealer for all endodontic cases; plus all the accessories you might need.

Also on display will be QED's range of own branded instruments including SteriFiles, both $\mathrm{H}$ and $\mathrm{K}$ type in sterile blister packs; triniti sterile nickel titanium rotary instruments, which are sensibly priced to suit most practitioners; and the Mtwo system, which is one of the top selling rotary files in Europe.

Reader response number 64 